\title{
COST OF PRODUCTS MANUFACTURED IN ORGANIZATIONAL SIMILAR GROUPS - CASE STUDY
}

\begin{abstract}
Janusz Mleczko
S u m m a r y

The paper presents selected aspects of production management related to the product customization. Product customization leads to an exponentially increased number of product and process variants, which exaggerates the difficulties in manufacturing in make-to-order production systems. The direct consequence of product customization on production is evidenced by an exponentially increased number of process variants, such as diverse machines, tools, fixtures, setups, cycle times and labors. In the production of mass customization a very important issue is changeovers times. In spite of applying modern management techniques, setup time still plays an important part in the production cycle time. The case study includes the manufacture of roller shutters. This paper presents a method of cost calculation taking into account the manufacturing roller shutters in organizational similar groups. The main purpose of this method is to identify range of costs of elements. The method was validated in the conditions of best practice production for high-variety production.
\end{abstract}

Keywords: group technology, mass customization, costs, product family

\section{Koszty wyrobów wytwarzanych w grupach organizacyjnie podobnych - studium przypadku}

$$
\text { Streszczenie }
$$

W artykule przedstawiono wybrane zagadnienia zarządzania produkcją związane $z$ dostosowaniem wyrobów do potrzeb klienta. Zjawisko kastomizacji produkcji prowadzi do wzrostu różnorodności wyrobów finalnych. Powoduje więc zwiększenie stopnia złożoności problemów zarzadzania produkcją. Bezpośrednią konsekwencją kastomizacji produkcji jest zwiększenie liczby wariantów procesu wytwarzania, tendencja do poszerzenia parku maszynowego, asortymentu narzędzi, oprzyrządowania oraz zwiększenia liczby przezbrojeń. Jednocześnie zwiększa się długość cyklu produkcyjnego oraz nakładów pracy. W produkcji masowej jednym z podstawowych czynników efektywności wytwarzania jest czas przezbrojeń. Omówiono zagadnienie dla produkcji rolet zewnętrznych. Przedstawiono metodę zmniejszania czasu przezbrojeń, obniżania kosztów wytwarzania przez tworzenie grup organizacyjnie podobnych. Metodę poddano weryfikacji w warunkach produkcji wielowariantowej w rzeczywistych warunkach produkcyjnych.

Słowa kluczowe: technologia grupowa, kastomizacja produkcji, koszty, rodzina wyrobów

\section{Introduction}

Address: Janusz MLECZKO, Ph.D. Eng., University of Bielsko-Biała, Department of Industrial Engineering, 43-309 Bielsko-Biała, Willowa 2, Poland, phone: $(0-48,33) 8272$ 253, e-mail: jmleczko@ath.bielsko.pl 
The facade of a room is usually composed of different construction elements, one of which is the window. Buildings in southern Europe are subject to a considerable number of hours of exposure to sunlight every year. To reduce solar radiation in the rooms of residential buildings, the opening in the facades is usually closed by means of a window with a rolling shutter [1]. In central Europe, except reducing solar radiation rolling shutters are also used as heat isolator. Due to the placement on the facade of the building customers require a large diversity of product that fulfil their specific individual requirements. These types of products are produced under conditions of mass customization. Producing customized products at a low cost, which seemingly is a paradox, is the purpose of many enterprises [2]. This main purpose, which is considered as fulfilling customer needs, results in production by unit and small batch process. The production cycle consists of, among others: the processing time and setup time. For high-variety production the cumulative amount of setup time results from the number of changeovers [3].

To shorten the production time and reduce costs for many years the methods of group technology are used [4]. The research in industry inspired the author to prepare a method of shorten the setup time based on the similarity of the products. The similarity is based on the features of tasks having influence on changeover times and optimization of task arrangement [5, 6].

The paper is structured as follows. First, the studied problem is shortly described. Then, an example to illustrate the problem is presented. Main part of the article consists of the method of calculation production costs in conditions of mass customization. Computational results are also discussed. The article concludes with some summary remarks.

\section{Problem background}

Increase product portfolio in response to customer requirements has an impact on costs and delivery time. The main questions are: What are the options and how many product variants to offer? How to manufacture the products? How to shorten the delivery time at the lowest cost?

The way of addressing these questions is a concept of Mass Customization. The concept of Mass Customization (MC); producing customized goods at low costs received considerable attention in the literature [7-10]. To implement product customization, many companies have changed their business models from make-to-stock to configure-to-order [11]. Configure-to-order (CTO) has been recognized as an ideal model that provides a right amount of product variety and a quick response time to customer orders [11, 12]. In CTO, final products are configured from a set of predefined modules and components subject to the constraints among them. While production in CTO starts 
after receiving of a customer order, order fulfillment starts from order processing [11].

Focusing on reducing the cost of offeed product variety, Gupta and Krishnan [13] propose a methodology for designing product family based on assembly sequences from semiproducts. Kusiak et al. discuss the design of assembly systems for modular products $[2,14]$.

A risk and limit of mass customization is known as "mass confusion", which is a metaphor for the burden of the consumer resulting from attractive but probably overloaded options $[15,16]$. More and more often, small and mediumsized enterprises (SME) are using software to increase the functionality of their products and offerings.

Variability management by software is becoming an interesting topic for SME with expanding portfolios and increasingly complex product structures. Sinnema \& Deelstra classified variability modeling techniques [17].

Software product family process evaluation is relatively a young area of research. Current, scientists have invented a systematic way to measure the functionality of the software product family process [18]. Software variability management is a key factor in the success of software systems and software product families. In [19] Deelstra et al. described the requirements for software variability management. To utilize commonality, underlying product diversity and process variation, it has been a widely accepted practice to develop product families, in which a set of similar variants share common product and process structures and variety differentiates within these common structures [11, 20, 21].

\section{Problem formulation}

The problem discussed in this paper concerns the analysis of the cost of producing product families. It is connected with the development of methods for calculating cost of the product family in a multivariate analysis taking into account the dynamic classification. Hence the need to answer the question: are the standard methods of calculating costs available for use in conditions of mass customization? The main problem results from the variability in organizational conditions. The method should be accurate and computationally efficient so that at the stage of confirmation of order the value of cost of products produced in the current organizational conditions, can be determined. Due to the number of changeovers to mass customization profitable, production must be based on the group technology (GT). Using the GT methods the similarity of the products is analyzed.

If organizational factors such as the desired delivery date, the current availability of resources will not be included, and the cost calculations would be charged with an error. Too high values will result in rejection of the contract by the customer while too low will result in a sale below cost. In summary, the 
methodology to solve the problem of calculating the cost of customized products is to answer the following questions:

How to define the algorithm for of calculating the cost of products and their components manufactured in conditions of GT?

Is it possible to determine the cost of the product at the stage of confirmation of order?

To illustrate the above problem, a simple example from industry is given.

\section{Ilustrative Example}

The example in this paper is the customization and production of product families for roller shutters manufactured in SME. Roller shutters are one example of family products.

The shutter can be made in many options. Product elements are given in Fig. 2. The main optional features are: system profile, dimensions: height and width of the blinds, color, drive type and others.

A crucial role in waste-free manufacturing of roller shutters is played by the rollforming line. The production of the product (product family) as shown in Fig. 1 assumes zero waste of roller shutters. It is possible to produce, in one process, a complete roller shutter curtain. The rollforming line is equipped with tooling suitable to produce the foamed roller shutter profiles in different sizes. The process consists of foaming, punching and cutting to length operations. The line is designed for high density or low density foamed profiles. The process can be implemented by alternative routes (Fig. 2).

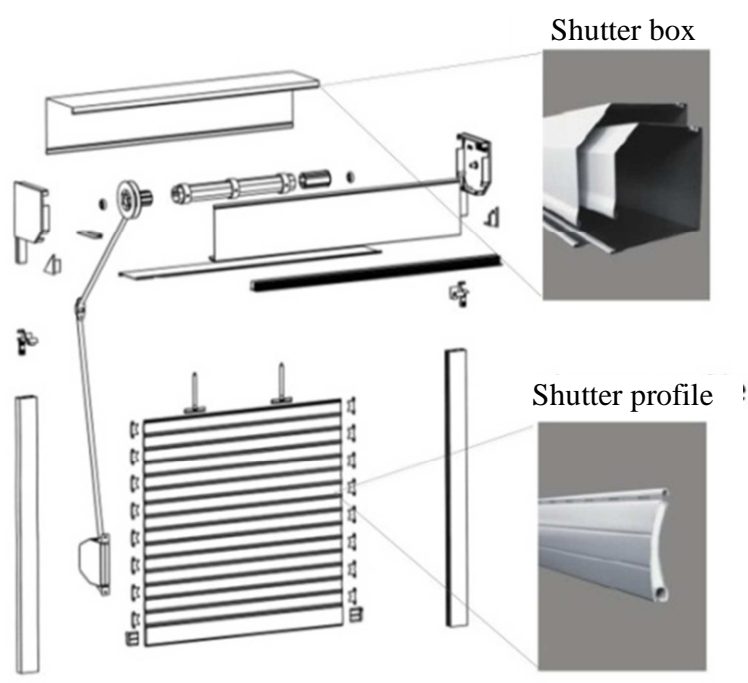


Fig. 1. Roller shutter's components
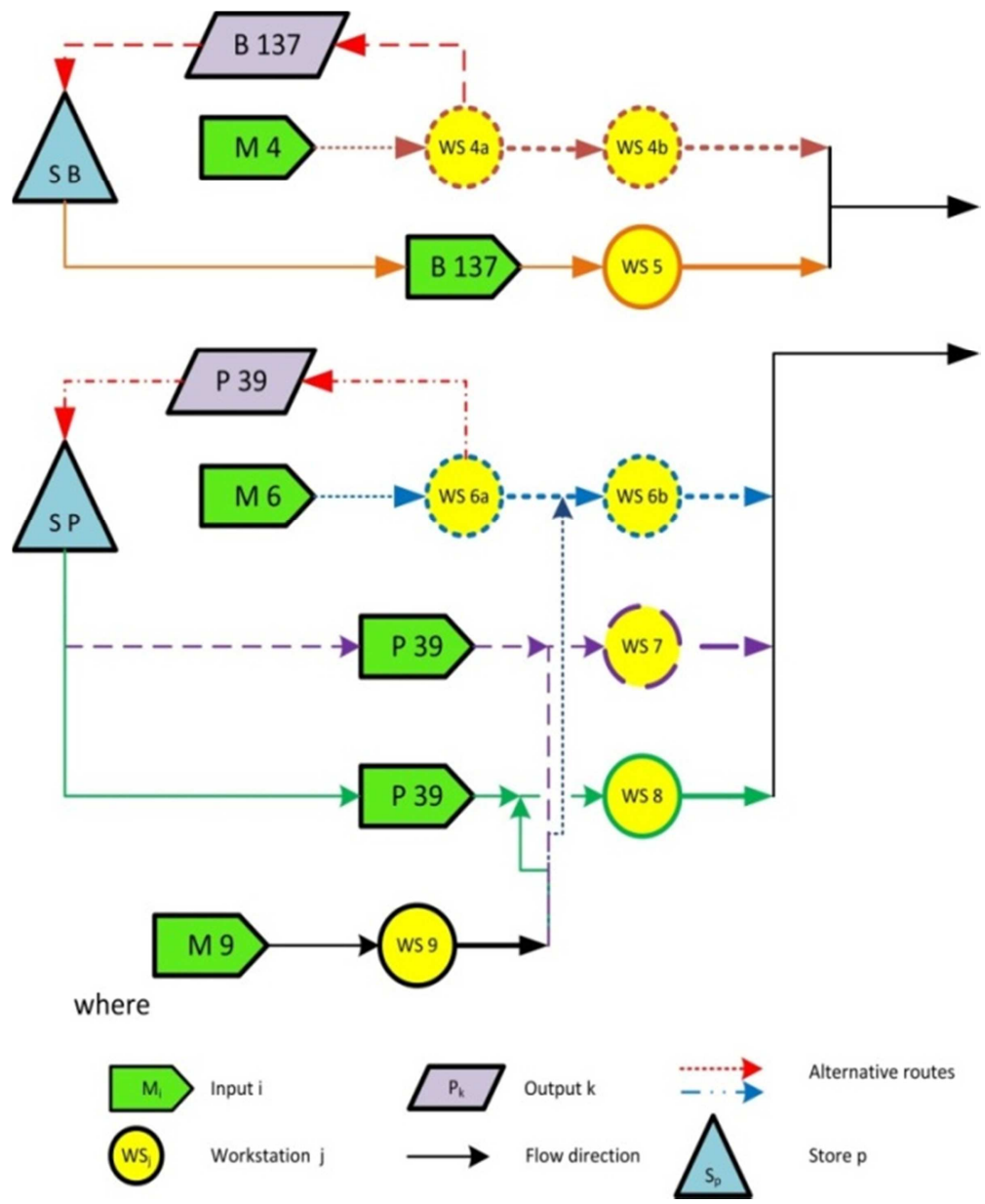

Fig. 2. Alternative routes of the manufacturing process

\section{Solution method}

In conditions of small and unit batch production a calculation of unit cost of each component in isolation from the grouping process which depends on the organizational conditions is too far-reaching simplification. Cost analysis should take into account the possibility of grouping the item with others in the organizational similar groups. Manufacturing elements with GT, using the processing time and cost are depended on the counts of the groups. On cost of manufacturing in conditions of mass customization the key role have the setup time. Reducing the setup time has a significant impact on unit cost of 
production. Currently, a lot of methods of calculating costs of production are used. In each of the methods the most important are the direct costs [22].

The component $K s t b_{i}$ (workstations costs of $i$-th product) is the sum of the costs of each operation of the manufacturing process $(o)$ :

$$
K_{s t b_{i}}=\sum_{o=1}^{O} K_{s t b_{i}}^{o}
$$

Unit cost of a single operation $K^{o}{ }_{s t b_{i}}$ results from the number of performed elements. It consists of two components:

$$
K_{s t b_{i}}^{o}=\text { Ksetup }_{I d_{i}}+K \text { work }_{I d_{i}}
$$

Component of direct cost associated with the changeover time Ksetup ${ }_{I d_{i}}$ is related to the production batch size. The larger the batch size is, the smaller is the share of the cost associated with the changeover attributable to unit cost. Hence, in the case of unit production share of a cost component associated with the changeover is relevant.

\section{Verification of the method}

To confirm this thesis and to determine the cost of the product with the organizational grouping verification by testing the selected company A was done. The test object was the production system described in section II. The study analyzes the organizational similar groups formed in 2011. The Table 1 shows the multiplicity of existing orders for the parameter type PA39 and color combinations. The main parameter influencing the changeover of the line is the type of the profile and the color of the curtain. For elements listed in Table 1 a detailed analysis of counts formed groups were done. The time structure of value P7 parameter is varied. The number of elements within the group was examined. In the cases of P7\#-BI and P7\#-BR are the largest groups. For values of the parameter P7\#CD groups are rare and of low size, although the same manufacturing process parameter P7 affects the costs.

From the above analysis it can be assumed that the cost of producing a from profile $\mathrm{P} 7 \#-\mathrm{BI}$ and $\mathrm{P} 7 \# \mathrm{BR}$ is lower than the cost of the product with the profile $\mathrm{P} 7 \# C D$. It resulted from the number of elements in each group. The problem to solve is to calculate the cost of the product and its components manufactured with the use of grouping. In this case, and many other similar systems, the production takes place in alternative manufacturing routes. 
Table 1. The number of orders within organizational similar groups

\begin{tabular}{|c|c|c|c|c|c|c|c|c|c|c|c|c|c|c|}
\hline $\begin{array}{c}\text { P7 } \\
\text { week }\end{array}$ & $\begin{array}{l}z \\
z \\
z\end{array}$ & $\begin{array}{l}\underset{\mathbf{m}}{\mathbf{m}} \\
\mathbf{z}\end{array}$ & $\overline{\underline{m}}$ & $\begin{array}{l}\frac{\alpha}{9} \\
\text { : }\end{array}$ & ટે & 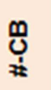 & 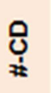 & 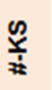 & $\sum_{i=1}^{\frac{x}{2}}$ & $\begin{array}{l}\text { 品 } \\
\underset{1}{1}\end{array}$ & $\begin{array}{l}\frac{\alpha}{6} \\
\text { wat }\end{array}$ & \begin{tabular}{l}
$\mathbb{N}$ \\
\hdashline
\end{tabular} & $\underset{\sharp}{\mathbb{N}}$ & ڤ્ \\
\hline 2 & & & 8 & 1 & & & & & & & & 3 & & 12 \\
\hline 3 & & 1 & 26 & 8 & & & 3 & & & 2 & & & 1 & 41 \\
\hline$\ldots$ & & & & & & & & & & & & & & \\
\hline 13 & & 14 & 17 & 22 & 3 & 2 & & 4 & & 19 & & 20 & 30 & 131 \\
\hline 14 & 9 & 22 & 24 & 20 & 12 & 18 & & 2 & & 49 & 5 & 16 & 34 & 211 \\
\hline 15 & & 9 & 19 & 26 & & 23 & 3 & 19 & & 14 & 5 & 8 & 31 & 157 \\
\hline 16 & 5 & 21 & 41 & 3 & & 4 & 5 & & & 38 & 6 & 21 & 8 & 152 \\
\hline 17 & & 4 & 19 & 29 & & 15 & 2 & 4 & 7 & 1 & & 7 & 9 & 97 \\
\hline 18 & 7 & 23 & 17 & 19 & & 5 & & 8 & & 27 & 4 & 3 & 1 & 114 \\
\hline 19 & & 16 & 34 & 59 & 4 & 14 & 9 & 1 & 1 & 28 & 3 & 6 & 13 & 188 \\
\hline$\cdots$ & & & & & & & & & & & & & & \\
\hline 33 & & 2 & 42 & 18 & & 27 & & & 8 & 2 & 7 & 6 & 23 & 135 \\
\hline 34 & & 13 & 34 & 35 & 2 & 9 & & 9 & 3 & 13 & 1 & 7 & 25 & 151 \\
\hline 35 & & 29 & 35 & 9 & & 10 & & & 2 & 15 & & 15 & 6 & 121 \\
\hline 43 & & 17 & 35 & 17 & 23 & 4 & & & & 12 & 13 & 12 & 34 & 167 \\
\hline 44 & & 7 & 40 & 29 & & 7 & & 9 & & 34 & 8 & 6 & 42 & 182 \\
\hline 45 & 1 & 28 & 24 & 28 & 15 & 11 & & 1 & 1 & & & 13 & 31 & 153 \\
\hline$\ldots$ & & & & & & & & & & & & & & \\
\hline sum & 119 & 605 & 1727 & 1232 & 124 & 723 & 31 & 194 & 94 & 830 & 298 & 603 & 917 & 7497 \\
\hline
\end{tabular}

P7 - the value for the number of the week, \#-AN, \# BE, ... - the colors of the panels

In the first variant production takes place entirely on the rollforming line. Changeover time is long and it is 1-2 hours. Waste material is approximately 12 $\mathrm{m}$ of tape needed to start the line. The values of direct costs in the first variant is:

$$
{ }^{I} K b_{i}={ }^{I} K m b_{i}+{ }^{I} K s t b_{i}
$$

where: ${ }^{I} K m b_{i}-$ material costs for $i$-th element in the first variant, ${ }^{I} K s t b_{i}$ - workstation costs for $i$-th element in the first variant

$$
{ }^{I} K m b_{i}=\left(s_{i} \cdot l_{i}+d_{w}\right) \cdot c_{i}
$$


where: $s_{i}$ - the width of the $i$-th element (curtain), $l_{i}$ - number of blades in curtain, $d_{w}$ - length of the tape resulting from the start of line, $c_{i}$ - price of raw material (1 $\mathrm{m}$ of tape)

$$
{ }^{I} K s t b_{i}=\left[\left(s_{i} \cdot l_{i}+d_{w}\right) \cdot{ }^{I} t_{m}+F \operatorname{setup}_{m}\right] \cdot k_{m}
$$

where: ${ }^{I} t_{m}$ - efficiency of rollforming and assembly line $(m), \mathrm{m} / \mathrm{h}$, Fsetup $_{m}$ - changeover time of $m$ line, $k_{m}$ - workstation costs per hour of $m$ line.

The cost of the $i$-th element manufactured with grouping in the first variant:

$$
{ }^{I} K b_{i}=\left(s_{i} \cdot l_{i}+\frac{d_{w}}{n_{e}}\right) \cdot c_{i}+\left[\left(s_{i} \cdot l_{i}+d_{w}\right) \cdot{ }^{I} t_{m}+\frac{\text { Fsetup }_{m}}{n_{e}}\right] \cdot k_{m}
$$

where: $n_{e}$ - count of elements manufactured within organizational similar group Oe.

In the second variant semi-product is manufactured on the rollforming line. The semi-product is the $6 \mathrm{~m}$ profile. Changeover time of line and waste material for the semi-product production is the same as in the first variant. The difference is that they can produce a larger number of semi-products and then use it in the further process. The problem is the semi-product waste in cutting. Depending on the width of the curtain waste ranges from 5 to even $15 \%$.

The values of direct costs in the second variant:

$$
{ }^{I I} K b_{i}={ }^{I I} K m b_{i}+{ }^{I I} K s t b_{i}
$$

where: ${ }^{I I} K m b_{i}-$ material costs for $i$-th element in the second variant, ${ }^{I I} K s t b_{i}-$ workstation costs for $i$-th element in the second variant

$$
{ }^{I I} K m b_{i}=\left(s_{i} \cdot l_{i}+d_{w}\right) \cdot c_{i} \cdot d_{i}
$$

where: $d_{i}$ - waste factor connected with the production from semi-products.

For the second variant assumed $d_{w} / n \approx 0$, where $n$ - count of semiproducts manufactured without changeovers.

$$
{ }^{I I} K s t b_{i}=\left[\left(s_{i} \cdot l_{i}+d_{w}\right) \cdot{ }^{I I} t_{m}+F \operatorname{setup}_{m}\right] \cdot k_{m}+\left({ }^{I I} \text { ta }_{i}+\text { Fsetup }_{a}\right) \cdot k_{a}
$$

where: ${ }^{I I} t_{m}$ - efficiency of rollforming line $(m)[\mathrm{m} / \mathrm{h}]$ (without assembly). 
In this case assumed ${ }^{I I} t_{m}>{ }^{I} t_{m},{ }^{I I} t a_{i}-$ cutting and assembly time, $k_{a}$ - workstation costs of cutting and assembly workstations (a) (per hour), Fsetup $_{a}$ - setup time of cutting and assembly workstations (a), in this case assumed Fsetup $\approx 00,{ }^{I I} k_{m}$ - workstatation costs per hour of $m$ line, in this case assumed ${ }^{I I} k_{m} \approx k_{m}$.

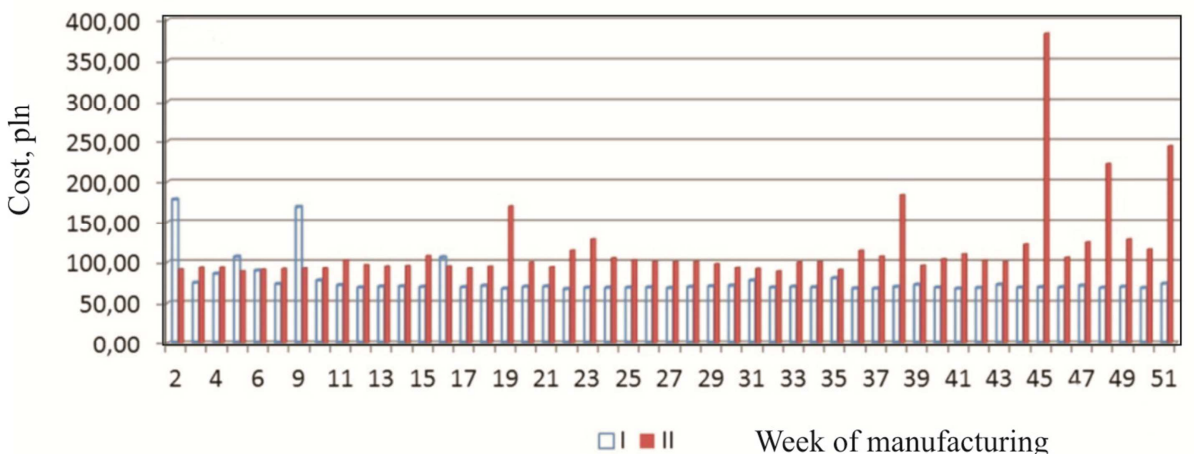

Fig. 3. The value of cost for elements with P7\#-BR the variants in 2011

When calculating the cost of changeovers with grouping for the manufacturing of semi-products, Fsetup ${ }_{m} / n \approx 0$.

$$
{ }^{I I} \mathrm{~Kb}_{i}=s_{i} \cdot l_{i} \cdot c_{i} \cdot d_{i}+\left[\left(s_{i} \cdot l_{i}+d_{w}\right) \cdot{ }^{I I} t_{m}\right] \cdot{ }^{I I} k_{m}+{ }^{I I} t_{i} \cdot k_{a}
$$

The calculations of costs for all values of the parameter P7 at five days aggregation for dynamic grouping were done. Selected results of calculation of direct cost (per $1 \mathrm{~m}^{2}$ of the shutter) manufactured in both variants are listed above (Fig. 3).

\section{Conclusions}

The contemporary customer requirements determine the production systems. Strategies for small and medium-sized enterprises are increasingly being directed towards the production of products with many options. Currently, production systems must be prepared to produce product families in the shortest possible production cycle and low cost. For this type of production method of costs calculating should focus on the analysis of the cost of the grouping at the stage of preparing the organization of production. The use of grouping leads to a reduction of time changeovers and thus reduce costs.

An introduced method of cost calculation allows a comprehensive assess ment of the impact of the option parameters on our products and their 
components manufactured in a production adjusted to customer's needs (mass customization). The method can provide a basis to implementation of the appropriate values of the matrix of discounts depending on the selected option of the product and the counts of elements produced with organizational similar grouping. Without adequate supporting information systems to carry out the calculation of cost of the stage and the order acceptance do not seem practicable. The study showed the possibility of reducing production costs both theoretical and achieved in practice. Both studies and practice have shown usability of the proposed manufacturing solutions.

\section{References}

[1] C. DÍAZ, A. PEDRERO: An experimental study on the effect of rolling shutters and shutter boxes on the airborne sound insulation of windows. Applied Acoustics, 70(2009), 369-377.

[2] C. CUNHA, B. AGARD, A. KUSIAK: Design for cost: module-based mass customization. Transactions on Automation Science and Engineering, 4(2007)3, 350-359.

[3] M. BARE, J.J. COX: Applying principles of mass customization to improve the empirical product development process. Journal of Intelligent Manufacturing, 19(2008), 565-576.

[4] A. KUSIAK: A generalized group technology concept. Inter. Journal of Production Research, 25(1987)4, 561-669.

[5] J. MLECZKO: Dynamic classification of tasks in condition of unit and small batch production. Management and Production Engineering Review, 1(2010)3, 41-55.

[6] J. MLECZKO: Product family manufacturing based on dynamic classification. Management and Production Engineering Review, 2(2011)2, 29-38.

[7] B.J. PINE: Mass Customization: The new frontier in business competition, Harvard Business School Press, Boston 1993.

[8] M. SPRING, J.F. DALRYMPLE: Product customization and manufacturing strategy. Inter. Journal of Operations \& Production Management, 20(2000)4, 441467.

[9] G. DA SILVEIRA, D. BORENSTEIN, F.S. FOGLIATTO: Mass customization: Literature review and research directions. Inter. Journal of Production Economics, 72(2001), 1-13.

[10] B. MACCARTHY, P.G. BRABAZON, J. BRAMHAM: Fundamental modes of operation for mass customization. Inter. Journal of Production Economics, 85(2003), 289-304.

[11] L. ZHANG, C. LEE, Q. XU: Towards product customization: An integrated order fulfillment system. Computer in Industry, 61(2010), 213-222.

[12] F. CHENG, M. ETTL, G. LIN, D.D. YAO: Inventory-service optimization in configure-to order systems. Manufacturing \& Service Operations Management, 4(2002)2, 114-132.

[13] S. GUPTA, V. KRISHNA: Product family-based assembly sequence design methodology. Transactions, 30(1998)3, 933-945. 
[14] A. KUSIAK, D.W. HE: Design of assembly systems for modular products. Transactions and Automation, 13(1997)5, 646-655.

[15] C. HUFFMAN, B. KAHN: Variety for sale: Mass customization or mass confusion. Journal of Retailing, 74(1998), 491-513.

[16] P. ZIPKIN: The limits of mass customization. MIT Sloan Management Review, 42(2001)3, 81-87.

[17] M. SINNEMA, S. DEELSTRA: Classifying variability modeling techniques. Journal of Information and Software Technology, 49(2007)7, 717-739.

[18] F. AHMED, L.F. CAPRETZ, J. SAMARABANDU: Fuzzy inference system for software product family process evaluation. Information Sciences, 178(2007), 2780-2793.

[19] S. DEELSTRA, M. SINNEMA, J. BOSCH: Variability assessment in software product families. Information and Software Technology, 51(2009), 195-218.

[20] J. JIAO, M.M. TSENG, Q. MA, Y. ZOU: Generic bill of materials and operations for high-variety production management. Concurrent Engineering, Research and Application, 8(2000)4, 297-322.

[21] J. JIAO, T.W. SIMPSON, Z.J. SIDDIQUE: Product family design and platformbased product development: a state-of-the-art review. Journal of Intelligent Manufacturing, 18(2007), 5-29.

[22] J. MATUSZEK, Z. KROKOSZ-KRYNKE, M. KOŁOSOWSKI: Rachunek kosztów dla inżynierów. PWE, Warszawa 2011. 